\title{
Feedback of tropical cyclones on El Niño diversity. Part I: Phenomenon
}

\author{
Qiuyun Wang ${ }^{1}$ · Jianping $\mathrm{Li}^{2,3,4}$
}

Received: 30 August 2021 / Accepted: 27 December 2021 / Published online: 31 January 2022

(c) The Author(s) 2022

\begin{abstract}
Understanding of the El Niño phenomenon is improving and several studies have considered the dynamics of El Niño diversity, however, the important role of tropical cyclones has rarely been reported. Here we show a clear feedback of tropical cyclones (TCs) over the western North Pacific (WNP) on the El Niño diversity. Strong (weak) accumulated cyclone energy helps to shift the center of strongest sea surface temperature anomalies 3 months later to the equatorial eastern (central) Pacific, and thus supporting the development of the eastern-Pacific (central-Pacific) El Niño. Local sea surface temperature anomalies in the Niño-3.4/Niño-3/Niño-4 region and tropical western Pacific, zonal wind anomalies over the tropical central-western Pacific and Madden-Julian Oscillation play small roles in the process that WNP TCs affect El Niño diversity. Moreover, the greater number of central-Pacific El Niño events after 1999/2000 may be associated with weaker accumulated cyclone energy in this period.
\end{abstract}

Keywords Tropical cyclones $\cdot$ Accumulated cyclone energy $\cdot$ El Niño $\cdot$ Diversity $\cdot$ Western North Pacific

\section{Introduction}

Since the pioneering study of El Niño-South Oscillation (ENSO) by Bjerknes (1969), considerable research has been devoted to the study of ENSO because of its large-scale effects (Wyrtki 1985; Zebiak and Cane 1987; Schopf and Suarez 1988; Battisti and Hirst 1989; Jin 1997; Weisberg and Wang 1997; Wang and Chan 2002; Chen et al. 2004; Chan 2007; Jin et al. 2014; Wang et al. 2016; Ding et al. 2017; Xie et al. 2018; Ren et al. 2020). Generally, El Niño/ La Niña and Southern Oscillation are together called ENSO, and El Niño is defined as the anomalous warming event that

Jianping Li

ljp@ouc.edu.cn

1 Key Laboratory of Mesoscale Severe Weather/Ministry of Education and School of Atmospheric Sciences, Nanjing University, Nanjing 210023, China

2 Frontiers Science Center for Deep Ocean Multispheres and Earth System (FDOMES)/Key Laboratory of Physical Oceanography/Academy of the Future Ocean, Ocean University of China, Qingdao 266100, China

3 Laboratory for Ocean Dynamics and Climate, Pilot Qingdao National Laboratory for Marine Science and Technology, Qingdao 266237, China

4 Department of Atmospheric Sciences, University of Hawai'i at Mānoa, Honolulu, HI 96822, USA happens over the central-eastern Pacific. As research into El Niño has advanced, El Niño diversity has been recognized based on its different characteristics. Thereinto, according to the location of the center of anomalous sea surface temperature (SST), El Niño diversity is identified by two types of the most common, the eastern-Pacific (EP) and central-Pacific (CP) El Niño (Ashok et al. 2007; Kug et al. 2009). Previous studies have demonstrated that El Niño is a key impact factor for tropical cyclone (TC) activity over the western North Pacific (WNP) on interannual timescales (Chia and Ropelewski 2002; Zhan et al. 2011; Ha et al. 2012; Han et al. 2016; Kang et al. 2019; Shin and Park 2020). The distinct types of El Niño have different influences on WNP TCs (Chen and Tam 2010; Kim et al. 2011; Wang et al. 2013; Patricola et al. 2018): during boreal summer, when there is an EP El Niño, although the number of TCs over the whole WNP changes little, there is a significant increase in TCs over the southeastern WNP. When there is a CP El Niño, the number of TCs over the whole WNP increases and the TCs occur farther westward.

In recent 20 years, the influence of TCs on the atmospheric and oceanic environment has attracted much interest (Sobel and Camargo 2005; Wada and Chan 2008), and the possible climate effects of TCs are coming under scrutiny (Hart 2011; Schenkel and Hart 2015). Previous studies (Hart et al. 2007; Wang et al. 2019) showed that the local 
memory of atmospheric and oceanic changes associated with a TC can persist over an extended period, so that TCs could contribute to the variation of SST over the eastern Pacific: the numerical experiments involving specified TC cases (Sriver et al. 2013) indicate TCs can excite equatorial Kelvin and Yanai waves, further suggesting that TC wind forcing may affect the timing and amplitude of El Niño events. Cross-equatorial TC pairs also play a role in the eastward expansion of equatorial warm SST anomalies in the Pacific (Keen 1982). The three-dimensional wind structures associated with westerly wind bursts (WWBs) and TCs are similar, and $\sim 69 \%$ of WWBs are associated with TCs in the western tropical Pacific (Lian et al. 2018). On interannual timescales, Camargo and Sobel (2005) first found an SST lagged signal using WNP accumulated cyclone energy (ACE) lag correlations with Niño indices for different seasons, and they suggested that ACE leads the Niño-3.4 index primarily because of the autocorrelation of SST anomalies in the Niño-3.4 region. Wang et al. (2019) found that the preceding ( 3 months earlier) WNP TCs could actually affect the El Niño intensity by a cumulative effect: the greater the ACE, the stronger the El Niño, particularly for TCs in July-September.

Generally, most studies have focused on the different influences of the distinct types of El Niño on the TCs over the WNP. Although some studies on the climate effect of TCs have been proposed, little is known about the feedback of TCs on El Niño diversity defined by the location of the maximum SST anomalies (in short, El Niño diversity). In this study, whether there is such feedback would be the key point concerned by us. In the follows in Sect. 2, the data and methods used in this study are presented. Section 3 shows the influence of the WNP TCs on EP and CP El Niño events. Section 4 discusses the influence of the WNP TCs on El Niño events related to the different preceding ACE strength. Section 5 summarizes the key conclusions and the related discussion.

\section{Data and methods}

\subsection{Data}

TC data of in the period 1970-2018 over the WNP is taken from the International Best Track Archive for Climate Stewardship (IBTrACS) from the National Oceanic and Atmospheric Administration (NOAA) (available online at https:// www.ncdc.noaa.gov/ibtracs/), here, via the China Meteorological Administration. The interpolated outgoing longwave radiation (OLR) data from NOAA for the period 1979-2018 are employed (available online at https://www.esrl.noaa.gov/ $\mathrm{psd} /$ data/gridded/data.interp_OLR.html). Monthly $2^{\circ} \times 2^{\circ}$ SST data from 1970 to 2018 is taken from the Extended
Reconstructed Sea Surface Temperature (ERSST) V5 dataset (Huang et al. 2017) (available online at https://www.esrl. noaa.gov/psd/data/gridded/data.noaa.ersst.v5.html/). Daily SST in the period 1979-2018 is obtained from ERA Interim dataset of European Centre for Medium-Range Weather Forecasts (ECMWF, available online at https://apps. ecmwf.int/datasets/data/interim-full-daily/levtype $=\mathrm{sfc} /$ ), on $2.5^{\circ} \times 2.5^{\circ}$ global grids. Monthly $2.5^{\circ} \times 2.5^{\circ}$ wind dataset for the period 1970-2018 is obtained from the National Centers for Environmental Prediction-National Center for Atmospheric Research (NCEP-NCAR) reanalysis dataset (Kalnay et al. 1996) (available online at https://www.esrl.noaa.gov/ psd/). Variables' anomalies after removing the effects of seasonality are calculated in this study, then they are processed by three-month running mean. All figures related to SST in this study are obtained by using ERSST V5 dataset, unless otherwise stated.

\subsection{ACE calculation}

As a comprehensively indicator, ACE includes many features of TCs, such as tracks, intensity and frequency (Bell et al. 2000). Meanwhile, it represents the accumulation of kinetic energy of TCs. Hence, ACE is suitable to study the climatic effect of TCs. As shown in the previous study (Wang et al. 2019), the ACE in each $2^{\circ}$ latitude $\times 2^{\circ}$ longitude grid cell is defined as the sum of the squares of the estimated 6-hourly maximum sustained surface wind speed (in $\mathrm{m} \mathrm{s}^{-1}$ ) for all TCs occurring in each grid cell over all 6-h periods; i.e., the grid cell ACE $=\sum_{i} V_{i}^{2}$, where $i$ is the $i$ th TC in a grid cell and $V$ is its maximum sustained surface wind speed. Thus, the ACE index is defined as the anomaly of the sum of the ACE for all grid cells in the selected region $\left(10^{\circ}-20^{\circ} \mathrm{N}\right.$, $135^{\circ}-170^{\circ}$ E) (Wang et al. 2019). This method of calculating ACE differs from the traditional method (Bell et al. 2000), and it could show the distribution of each grid cell. Strong (weak) ACE events are defined as having ACE index values of $\geq 0.5(\leq-0.5)$ standard deviations. The months in which strong (weak) ACE events occur are referred to as the strong (weak) ACE months.

\subsection{Definition of El Niño events}

The running 3-month mean of the SST anomaly in the Niño3.4 area $\left(5^{\circ} \mathrm{S}-5^{\circ} \mathrm{N}, 120^{\circ}-170^{\circ} \mathrm{W}\right)$ defines the Niño-3.4 index. According to the NOAA standard (https://www.cpc. ncep.noaa.gov/products/analysis_monitoring/ensostuff/ ONI_v5.php), El Niño events are generally defined when the Niño-3.4 index in five consecutive overlapping three-month periods is at or above the $+0.5^{\circ} \mathrm{C}$ anomaly. The year that El Niño develops from weak to strong defines the El Niño developing year (January-December), on the contrary, the El Niño decaying year is defined when El Niño decays from 
strong to weak. During these El Niño events, the months chosen for study are those with Niño-3.4 index at or above the $+0.5^{\circ} \mathrm{C}$ anomaly. Months in which El Niño occurs are called El Niño months. In this study, we main focus on the El Niño developing year and the peak time of El Niño.

\subsection{Types of El Niño events}

Similar to the method employed by previous study (Kug and Ham 2011), we define EP El Niño events when the normalized Niño-3 SST $\left(5^{\circ} \mathrm{S}-5^{\circ} \mathrm{N}, 90^{\circ}-150^{\circ} \mathrm{W}\right)$ is greater than 0.5 and also greater than the normalized Niño-4 SST $\left(5^{\circ} \mathrm{S}-5^{\circ}\right.$ $\left.\mathrm{N}, 160^{\circ} \mathrm{E}-150^{\circ} \mathrm{W}\right)$. CP El Niño events are defined when the normalized Niño-4 SST is greater than 0.5 and also greater than the normalized Niño-3 SST. The Niño-3 and Niño-4 SSTs are defined as the average during December-February. This gives 5 EP El Niño (1972-1973, 1976-1977, 1982-1983, 1997-1998, 2015-2016) and 8 CP El Niño events (1977-1978, 1979-1980, 1994-1995, 2002-2003, 2004-2005, 2006-2007, 2009-2010, 2014-2015). There are more events, which have features between those of $\mathrm{CP}$ and EP El Niño events: the 1986-88 El Niño events and 1991-92 events (Wang et al. 2013). These events are not included. Figure 1 shows the spatial distributions of the two types of El Niño events, and we find that the classification methods of El Niño are valid. Except for the traditional classification method of El Niño, we define cases related to the preceding ACE, so that we have three classes: the El Niño mean state (i.e., El Niño months) consisting of the SST anomalies in the months when the Niño-3.4 index is $\geq 0.5{ }^{\circ} \mathrm{C}$ during the
El Niño period, the El Niño_strong ACE case when the El Niño month is associated with preceding strong ACE, and the El Niño_weak ACE case when the El Niño month is associated with preceding weak ACE.

\subsection{Madden-Julian Oscillation (MJO)}

Based on a pair of empirical orthogonal functions (EOFs) of OLR, Wheeler and Hendon (2004) developed a seasonally independent multivariate MJO index. This index is defined by the sum of the squares of two leading principal components (PCs), i.e., $\mathrm{PC}^{2}+\mathrm{PC}^{2}$. MJO events defined by $\sqrt{\mathrm{PC}^{2}+\mathrm{PC}^{2}} \geq 1$, others considered to be non-MJO events. An MJO event is usually divided into eight phases. Generally, during the in phases 1-3 and 8, the convective center is located in the Indian Ocean; during the phases 4-7, the convective center propagates into the Pacific (Zhao et al. 2015). Thus, MJO events are divide into active (phases 4-7) and inactive (phases 1-3 and 8) MJO events.

\subsection{Dependent and independent variables}

Regression analysis is applied to obtain a dependent variable $\left(\tilde{\mathrm{z}}_{\mathrm{x}}\right)$ associated with an independent variable $(x)$, as Eq. (1):

$\tilde{\mathrm{z}}_{\mathrm{x}}=\mathrm{ax}+\mathrm{b}$

where $a$ and $b$ are the regression coefficient and a constant, respectively, and $\tilde{z}_{\mathrm{x}}$ is the part of $z$ associated with $x . z_{\mathrm{x}}^{*}$ is the $x$-independent $z$, which can be calculated as follows: (a)

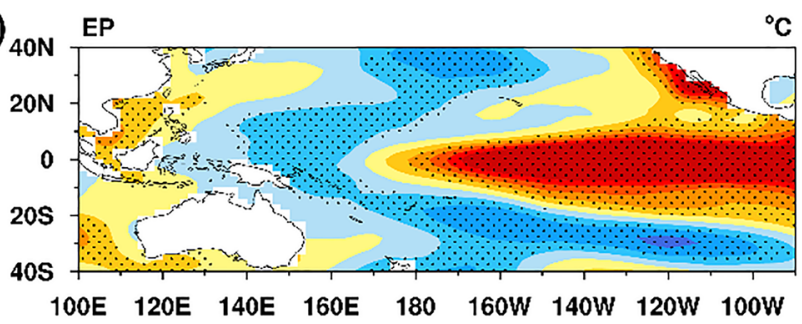

${ }^{\circ} \mathrm{C}$ (b)

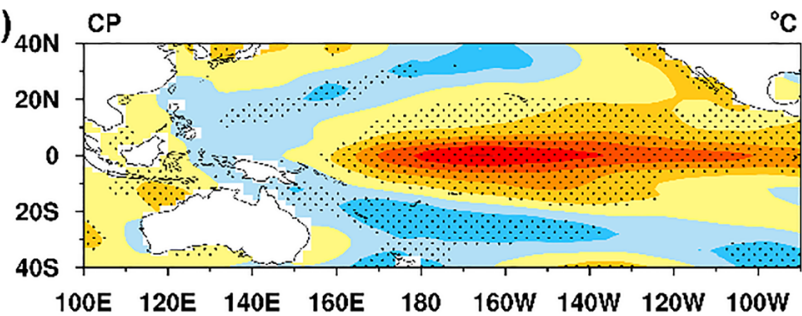

(c)

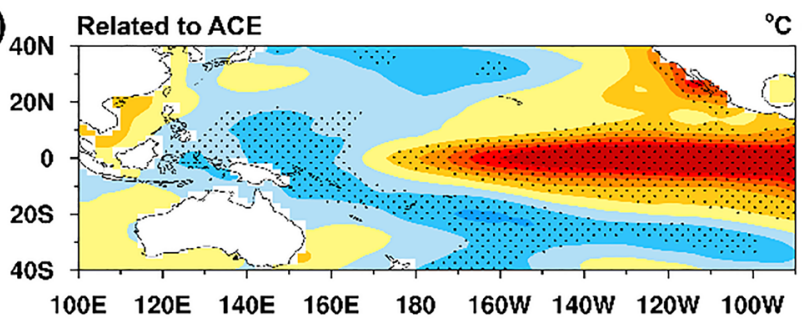

$C$ (d)

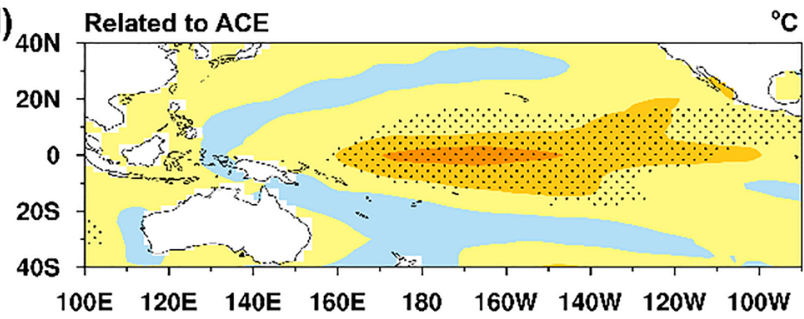

$\begin{array}{lllll}-1.25 & -1 & -0.75 & -0.5 & -0.25\end{array}$

$\begin{array}{lllllll}\mid & & & & & & \\ 0 & 0.25 & 0.5 & 0.75 & 1 & 1.25\end{array}$

Fig. 1 Spatial distribution of NDJ SST $\left({ }^{\circ} \mathrm{C}\right)$ anomalies during EP and CP El Niño events in the period 1970-2018. a Composite of SST anomalies (shading) during EP El Niño. The stippled regions denote statistical significance above the 95\% confidence level (Student's $t$-test). $\mathbf{b}$ As in $\mathbf{a}$, but for CP El Niño. $\mathbf{c}, \mathbf{d}$ As in $\mathbf{a}, \mathbf{b}$, but for the SST anomalies related to the preceding ACE anomalies over the WNP 


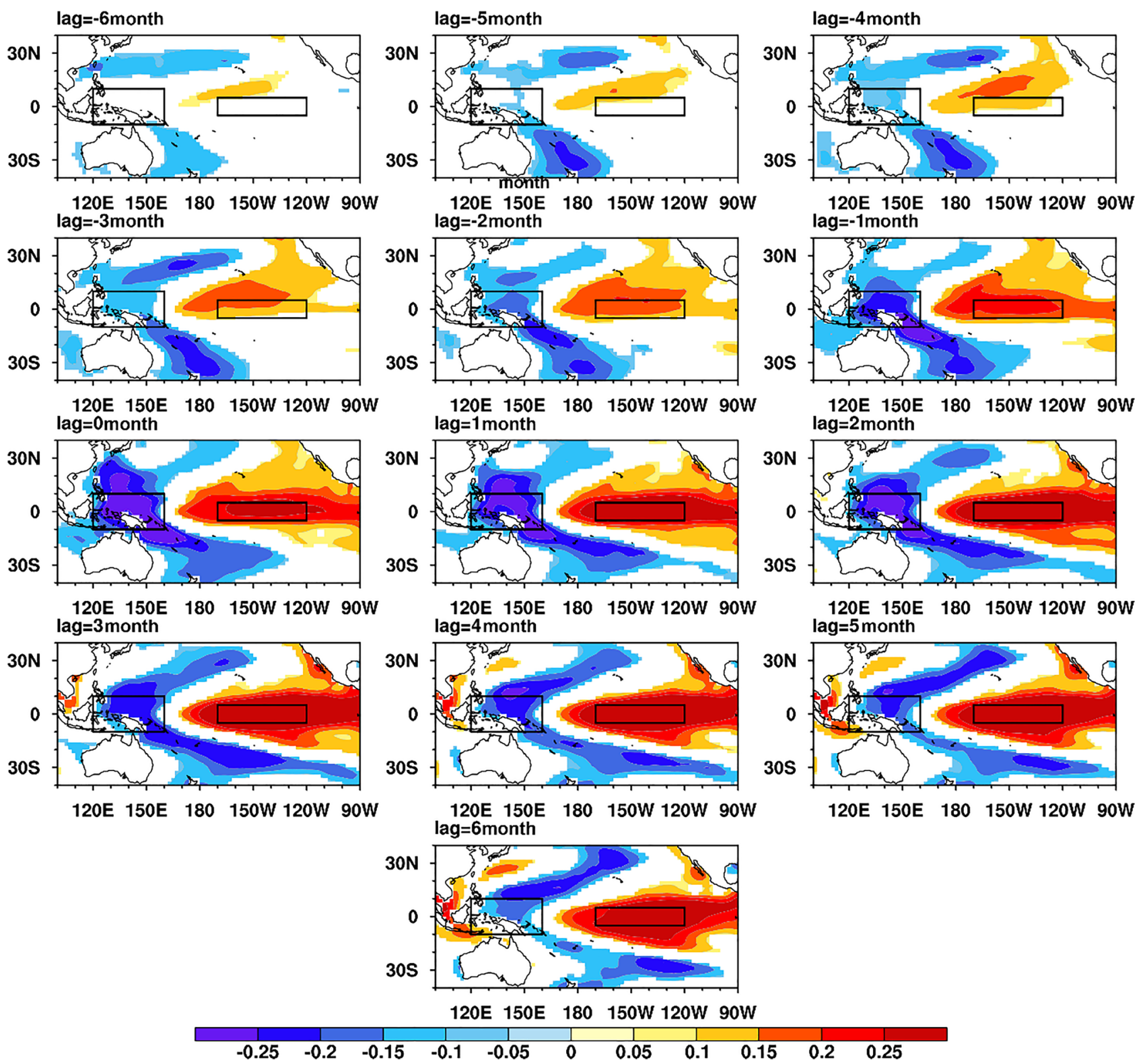

Fig. 2 Spatial lead-lag correlation between the WNP ACE anomalies and SST anomalies. The two black rectangles denote the Niño-3.4 region $\left(5^{\circ} \mathrm{S}-5^{\circ} \mathrm{N}, 120^{\circ}-170^{\circ} \mathrm{W}\right)$ and the selected SST region $\left(10^{\circ}\right.$

$\mathrm{z}_{\mathrm{x}}^{*}=\mathrm{z}-\tilde{\mathrm{z}}_{\mathrm{x}}$

Taking Figs. 1c and 5b as examples:

For Fig. 1c, Step 1, select SST anomalies of all EP El Niño years; Step 2, calculate the SST anomalies related to the preceding WNP ACE anomalies $\left(\tilde{\mathrm{z}}_{\mathrm{x}}\right)$ during the EP El Niño year using Eq. (1). Here, the dependent variable $(z)$ is SST anomalies, and the independent variable $(x)$ is the preceding WNP ACE anomalies; Step 3, composite the SST anomalies distribution from November to January (NDJ) during the EP El Niño years, thus Fig. 1c is obtained.
$\mathrm{S}-10^{\circ} \mathrm{N}, 120^{\circ}-160^{\circ} \mathrm{E}$ ), negative lag value indicate SST anomalies lead WNP ACE, and vice versa. Shading denotes statistical significance above the $95 \%$ confidence level (Student's $t$-test).

For Fig. 5b, Steps 1-2 are the same as in Fig. 1c; Step 3, the SST anomalies after removing the preceding WNP ACE anomalies $\left(\mathrm{z}_{\mathrm{x}}^{*}\right)$ are obtained using Eq. 2; Step 4, composite the zonal SST anomalies (along $5^{\circ} \mathrm{S}-5^{\circ} \mathrm{N}$ ) during the EP El Niño years.

Partial correlation analysis is employed to remove the signal of additional impact factors, like the local SST anomalies in the Niño-3.4 region and tropical western Pacific, the zonal 


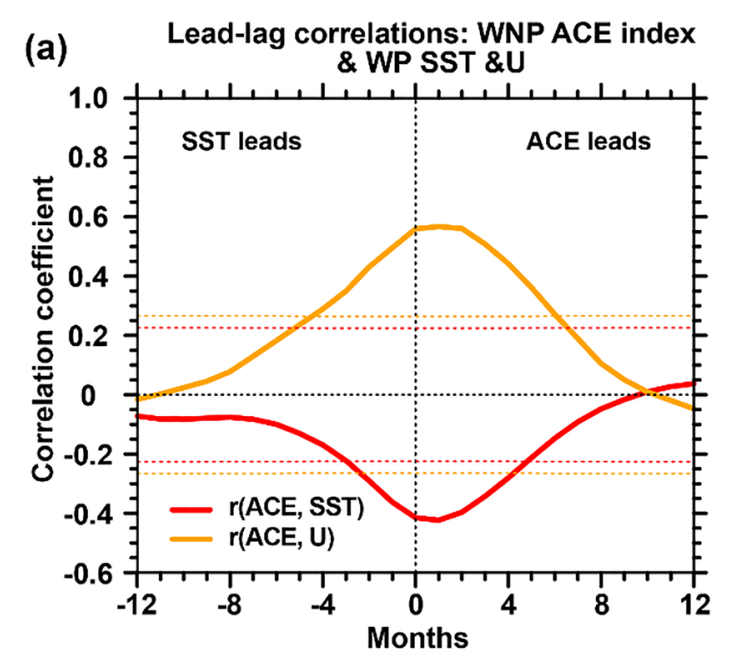

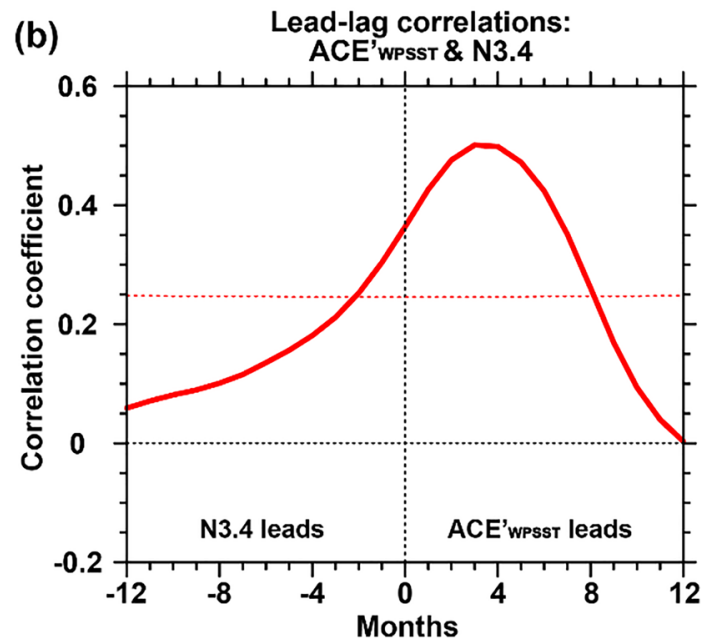

Fig. 3 Lead-lag correlations among the WNP ACE anomalies, SST anomalies in the tropical western Pacific $\left(10^{\circ} \mathrm{S}-10^{\circ} \mathrm{N}, 120^{\circ}-160^{\circ}\right.$ E), zonal wind anomalies over the tropical central-western Pacific $\left(10^{\circ} \mathrm{S}-10^{\circ} \mathrm{N}, 120^{\circ} \mathrm{E}-120^{\circ} \mathrm{W}\right)$ and the Niño-3.4 index in the period 1970-2018. a Lead-lag correlations between the WNP ACE anomalies and SST anomalies in the tropical western Pacific (red line) or zonal wind anomalies over the tropical central-western Pacific (orange line). And the red and orange dashed lines indicate the corresponding significance at the $99 \%$ confidence level via Student's $t$-test,

wind anomalies over the tropical central-western Pacific and the MJO.

\section{Influence of the WNP TCs on EP and CP EI Niño events}

\subsection{WNP TCs can affect the spatial distribution and evolution of El Niño events}

Apart from an underestimation of intensity, the characteristic spatial patterns of NDJ SST associated with El Niño events are captured well by the preceding (Here specifically refers

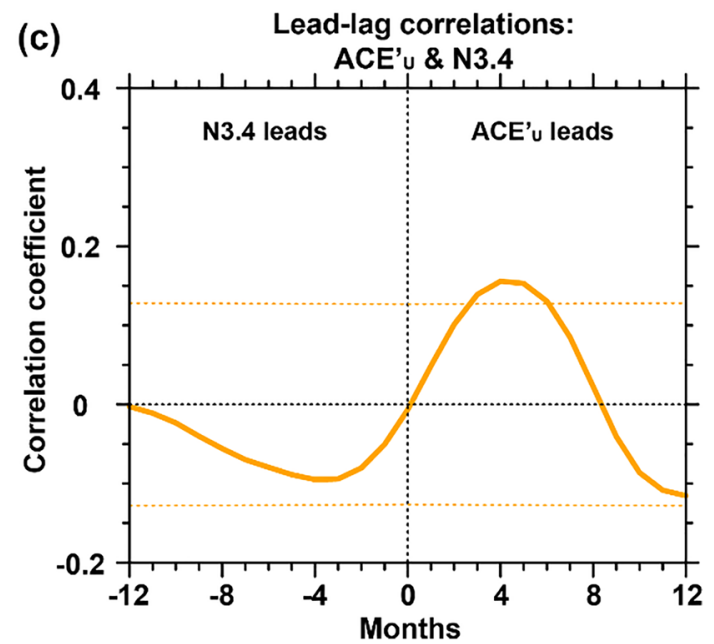

respectively. b Lead-lag correlations between the WNP ACE anomalies and Niño-3.4 index; here, WNP ACE index is that after removing the signal of SST anomalies in the tropical western Pacific. Red dashed line indicates the corresponding significance at the $99 \%$ confidence level via Student's $t$-test. c As in b, but the WNP ACE index is that after removing the signal of zonal wind anomalies over the tropical central-western Pacific. Orange dashed line indicates the corresponding significance at the $95 \%$ confidence level via Student's $t$-test

to August to October, ASO) ACE signal, for both EP and CP El Niño (Fig. 1a-d). Note that El Niño has some precursors that might independently affect TC activity, like the local SST, zonal wind over the tropical central-western Pacific and the MJO (Weisberg and Wang 1997; McPhaden 1999; Wang et al. 1999; Puy et al. 2016). The spatial lead-lag correlation between WNP ACE and SST anomalies indicates (Fig. 2) that the correlation coefficients between the WNP ACE and SST anomalies in the western Pacific are always negative, irrespective of the SST lead or lag. This negative correlation means that WNP TCs cannot be intensified by the warmer of SST anomalies in the western Pacific. The maximum negative correlation occurs in the region $10^{\circ}$ 
(a)

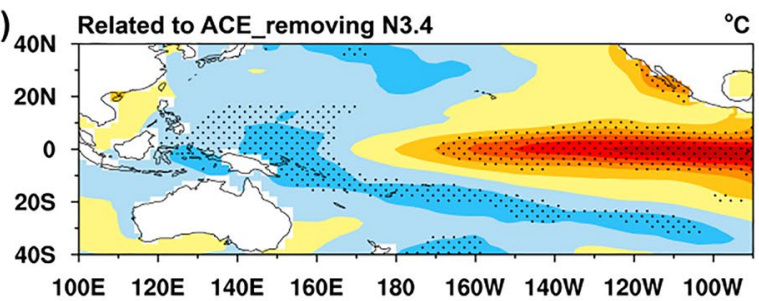

${ }^{\circ} \mathbf{C}$ (b)

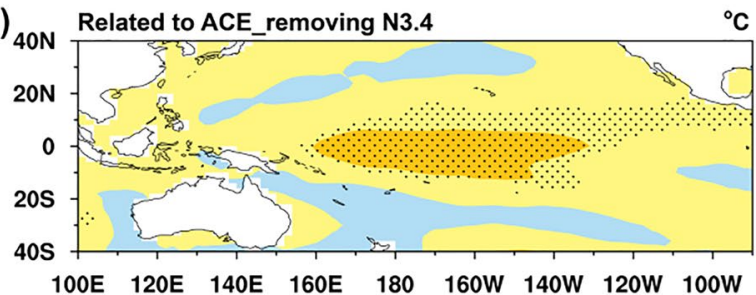

(c)

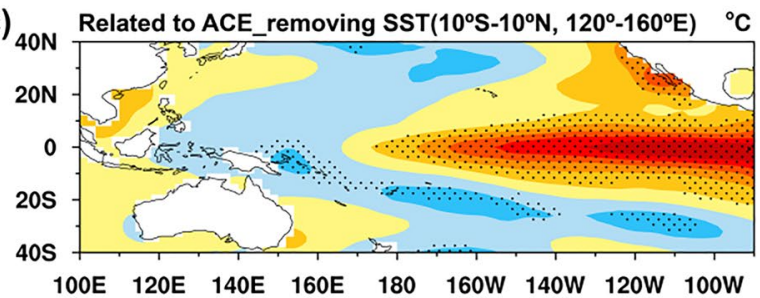

(d)

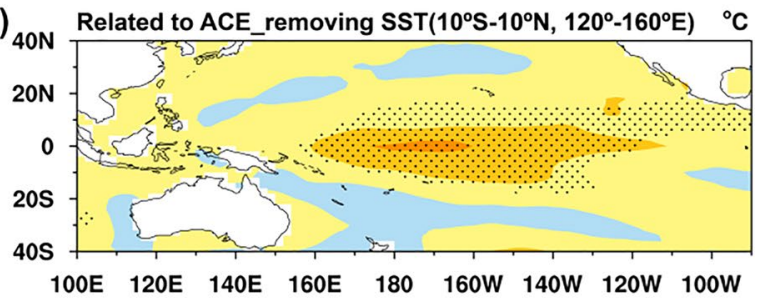

(e)

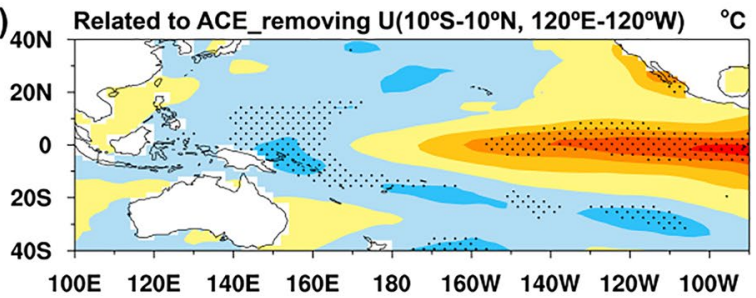

C (f)

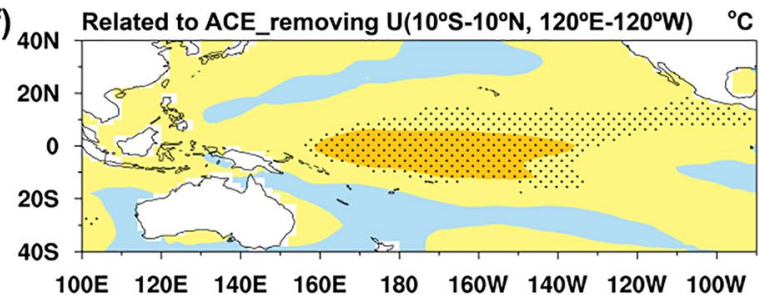

(g)

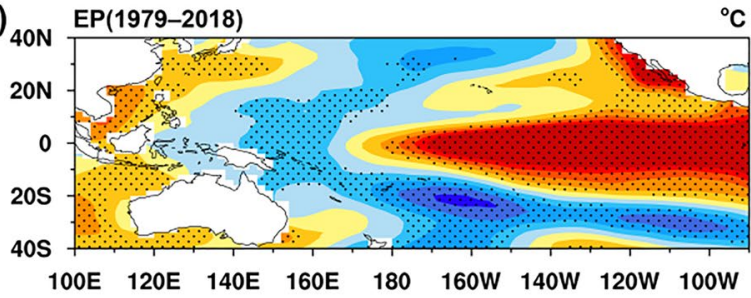

c (h)

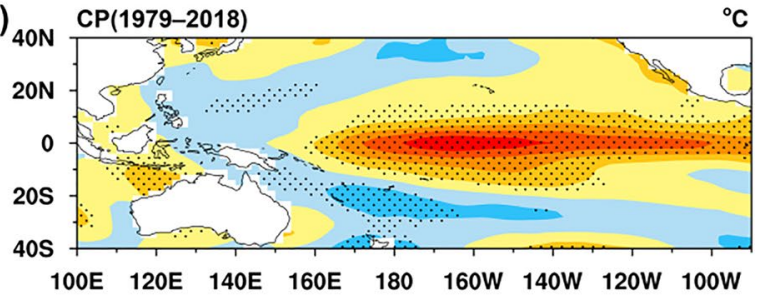

(i)

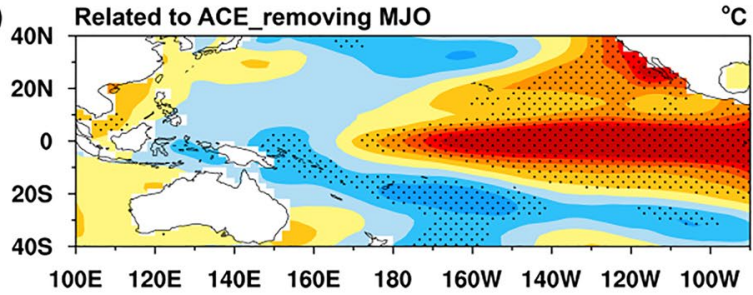

${ }^{\circ} \mathrm{C}(\mathrm{j})$

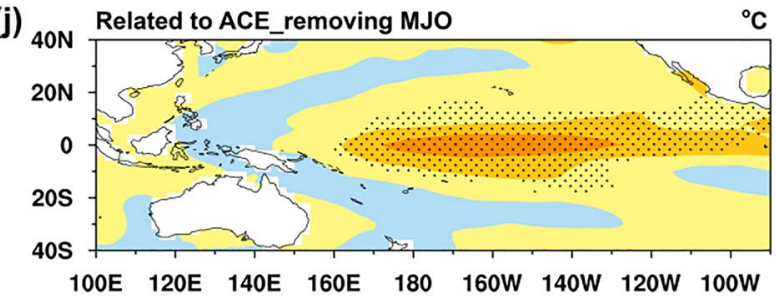

$\begin{array}{lllll}-1.25 & -1 & -0.75 & -0.5 & -0.25\end{array}$

Fig. 4 As in Fig. 1, but for the spatial distribution of the NDJ SST anomalies (shading, ${ }^{\circ} \mathrm{C}$ ) in the different situations. a SST anomalies associated with the preceding WNP ACE during EP El Niño event; here, ACE is obtained after removing the Niño-3.4 index. b As in a, but for CP El Niño event. $\mathbf{c}, \mathbf{d}$ As in $\mathbf{a}, \mathbf{b}$, but for the ACE obtained after removing the SST anomalies in the tropical western Pacific $\left(10^{\circ}\right.$ $\left.\mathrm{S}-10^{\circ} \mathrm{N}, 120^{\circ}-160^{\circ} \mathrm{E}\right)$. e, f As in $\mathbf{a}, \mathbf{b}$, but for the ACE obtained

$\mathrm{S}-10^{\circ} \mathrm{N}, 120^{\circ}-160^{\circ} \mathrm{E}$. Hence, we use the SST anomalies in this region to calculate the SST index of the tropical western Pacific. The lead-lag correlation between the WNP ACE and SST index of the tropical western Pacific indicates that the after removing the zonal wind anomalies in the tropical centralwestern Pacific $\left(10^{\circ} \mathrm{S}-10^{\circ} \mathrm{N}, 120^{\circ} \mathrm{E}-120^{\circ} \mathrm{W}\right)$. g Distribution of the NDJ SST anomalies during EP El Niño event in the period of 1979-2018. h As in $\mathbf{g}$, but for CP El Niño event. $\mathbf{i}, \mathbf{j}$ As in $\mathbf{g}, \mathbf{h}$, but for the SST anomalies associated with the preceding WNP ACE, and $\mathrm{ACE}$ is that after removing the MJO signal

negative correlation reaches its maximum when the WNP ACE leads (Fig. 3a). Meanwhile, the variation of zonal wind anomalies over the tropical central-western Pacific also lags 
Fig. 5 Spatial evolution of SST anomalies $\left({ }^{\circ} \mathrm{C}\right)$ during EP and CP El Niño events in the period 1970-2018. a Composite of

SST anomalies (shading) during EP El Niño. DJF-1 and DJF0 represent the December-February of the previous year and the year when the peak of El Niño occurs. b As in a, but for the SST anomalies after removing the effect of preceding WNP ACE anomalies. $\mathbf{c}, \mathbf{d}$ As in $\mathbf{a}, \mathbf{b}$, but for CP El Niño

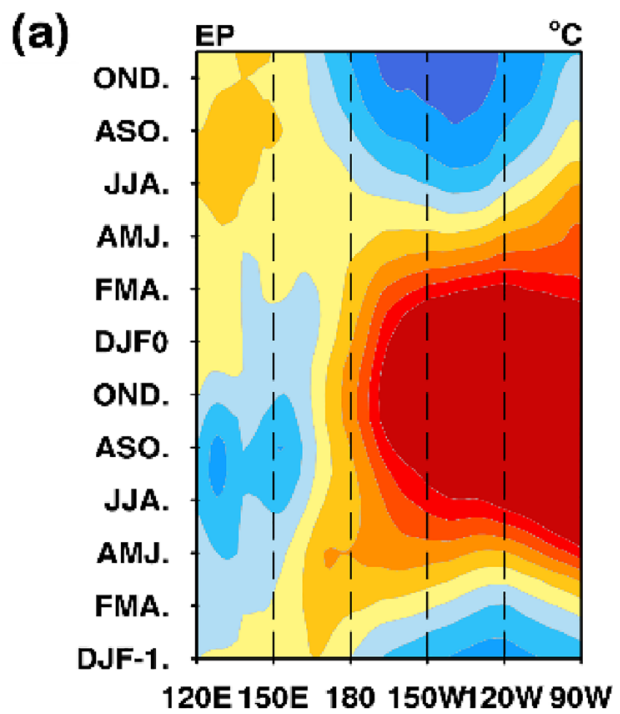

(c)

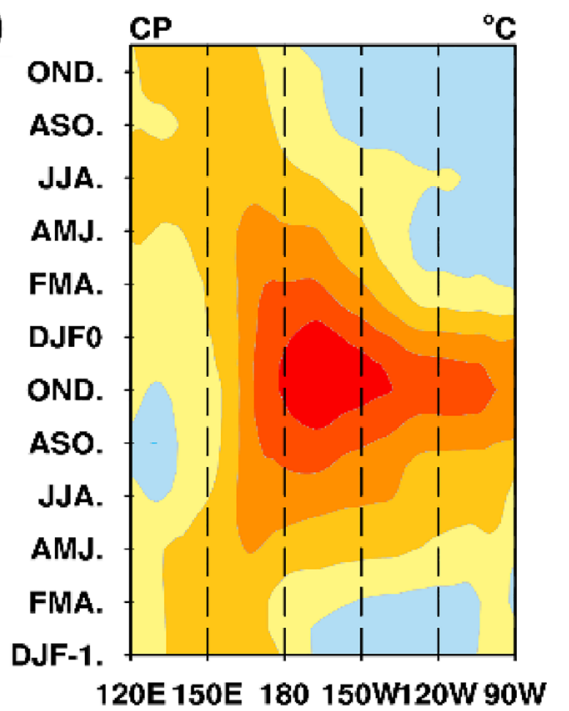

(b)

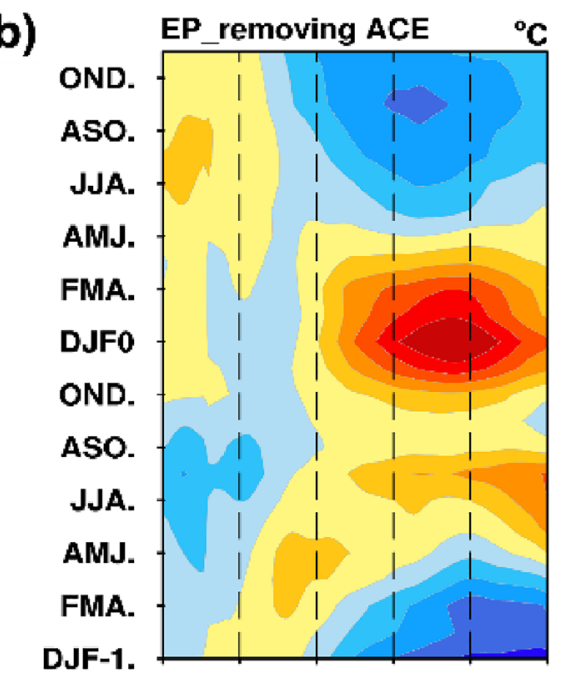

(d) 120E 150E 180150 W120W 90W

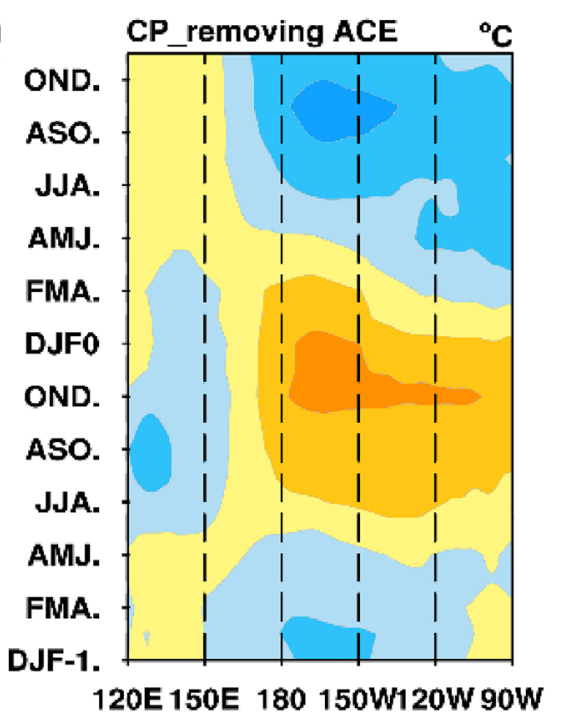

the change of WNP ACE (Fig. 3a). Moreover, like the cases of the SST anomalies in the Niño-3.4 region and the MJO (Wang et al. 2019), the SST anomalies in the tropical western Pacific and zonal wind anomalies over the tropical central-western Pacific do not affect the relationship in which the WNP ACE leads the Niño-3.4 index (Fig. 3b, c). In spite of this, it is necessary to examine further the roles of these four impact factors (the local SST anomalies in the Niño-3.4 region and tropical western Pacific, zonal wind anomalies over the tropical central-western Pacific and the MJO) in the process by which the WNP TCs affect the two types of El Niño events. As shown in Fig. $4 \mathrm{a}-\mathrm{d}$, when the simultaneous
SST anomalies in the Niño-3.4 region or tropical western Pacific are removed from the ASO WNP ACE signal, the ASO WNP ACE can still capture well the spatial characteristics of NDJ SST anomalies during the EP and CP El Niño events, although the intensities of the reproduced SST anomalies are weakened. A similar situation occurs when the zonal wind anomalies or MJO signal are removed from the ASO WNP ACE (Fig. 4e-j). Of the four impact factors, the zonal wind over the tropical central-western Pacific and SST anomalies in the Niño-3.4 region have the largest influences on the reproduced SST anomaly intensity, followed by the SST anomalies in the tropical western Pacific 

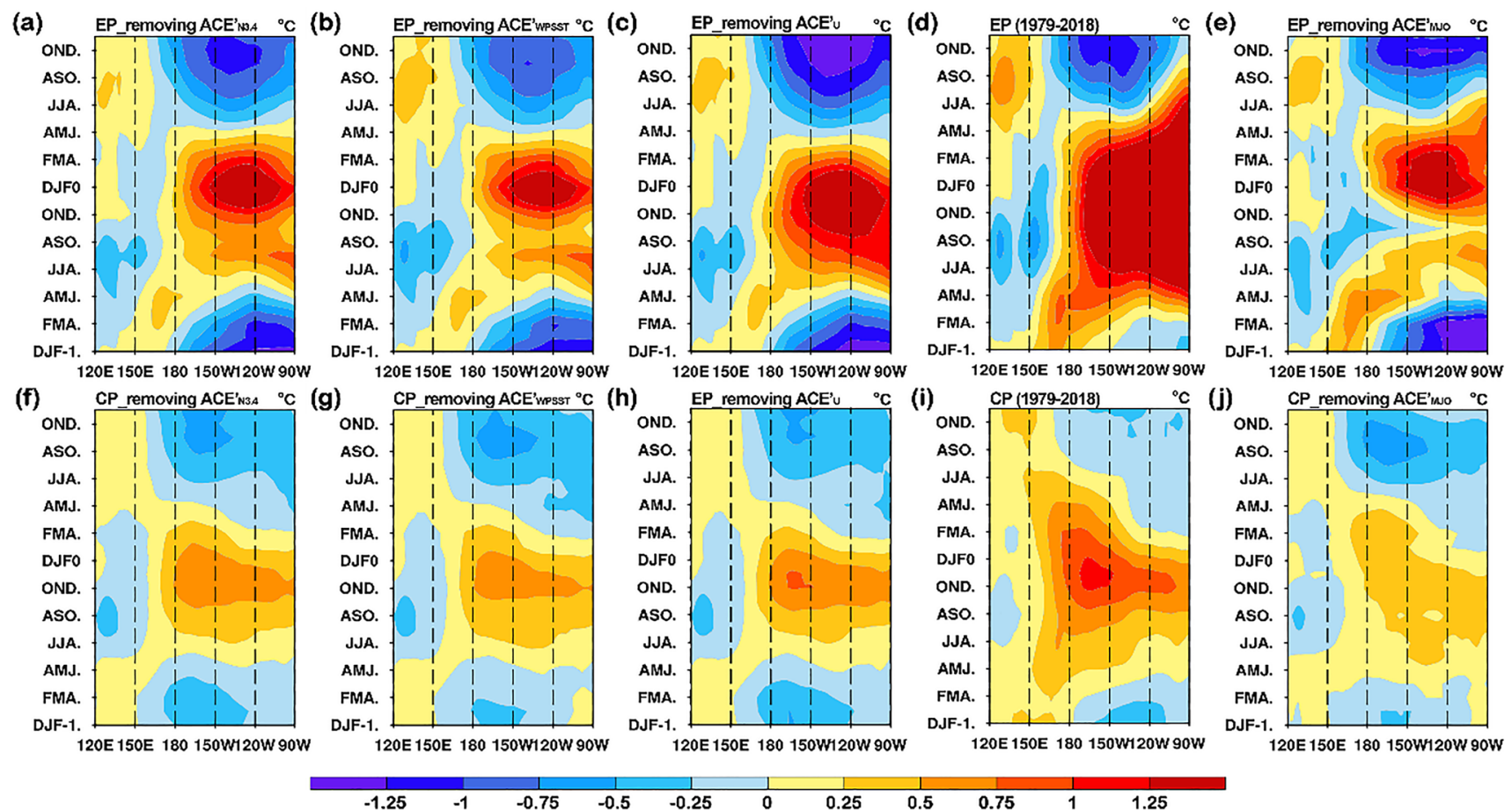

Fig. 6 Spatial evolution of SST anomalies $\left({ }^{\circ} \mathrm{C}\right)$ after removing the preceding WNP ACE anomalies during EP and CP El Niño events in the period 1970-2018; here, ACE is that after removing impact factor. a Spatial evolution of SST anomalies after removing the preceding WNP ACE during EP El Niño event; here, ACE is that after removing Niño-3.4 index. $\mathbf{b}$ As in $\mathbf{a}$, but for ACE is that after removing the SST anomalies in the tropical western Pacific $\left(10^{\circ} \mathrm{S}-10^{\circ} \mathrm{N}\right.$, $120^{\circ}-160^{\circ} \mathrm{E}$ ). c As in a, but for ACE is that after removing the zonal wind anomalies over the tropical central-western Pacific $\left(10^{\circ} \mathrm{S}-10^{\circ}\right.$ $\left.\mathrm{N}, 120^{\circ} \mathrm{E}-120^{\circ} \mathrm{W}\right)$. d Spatial evolution of SST anomalies during EP El Niño event in the period of 1979-2018. e As in d, but for the SST anomalies after removing the preceding WNP ACE, and ACE is that after removing the MJO signal. $\mathbf{f}-\mathbf{j}$ is as in $\mathbf{a}-\mathbf{e}$, but for CP El Niño events

Furthermore, the evolution of both EP and CP El Niño events changes evidently when the preceding ACE is removed (Fig. 5). During EP El Niño events (Fig. 5a, b), the evolution of the EP El Niño is interrupted when the preceding WNP ACE is removed and the largest change in spatial structure occurs during the developing year of El Niño. Meanwhile, the center of positive SST anomalies shifts to the west to $120^{\circ}-150^{\circ} \mathrm{W}$ during the decaying year of El Niño. During CP El Niño events (Fig. 5c, d), the SST anomalies reduce greatly to less than $0.5^{\circ} \mathrm{C}$ before November when the preceding ACE is removed, and the center of positive SST anomalies extends to the east. The local SST anomalies in the Niño-3.4 region and the tropical western Pacific, the zonal wind over the tropical central-western Pacific and the MJO cannot change the role of WNP ACE in the spatial evolution of SST anomalies during the two types of El Niño (Fig. 6).

Evidently, the WNP TCs can affect El Niño diversity. Combined with the conclusion of the previous study on 

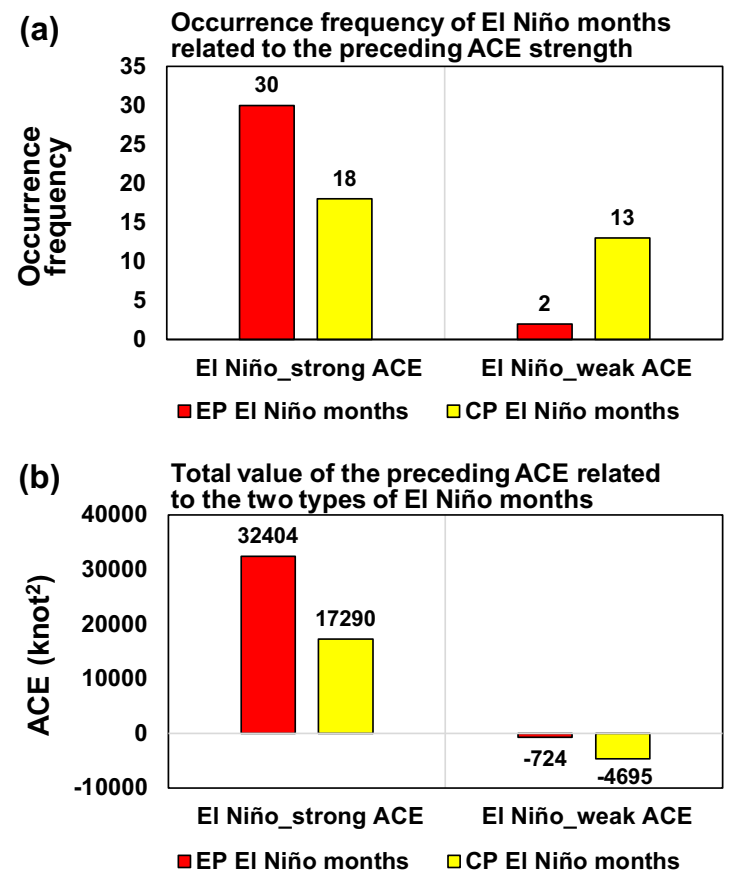

Fig. 7 Occurrence frequencies of El Niño months (a) associated with the preceding WNP ACE $\left(10^{\circ}-20^{\circ} \mathrm{N}, 135^{\circ}-170^{\circ} \mathrm{E}\right)$ and the corresponding preceding ACE anomalies $\left(\mathrm{knot}^{2}\right)(\mathbf{b})$ in the period 19702018

the impact of WNP TCs on El Niño intensity (Wang et al. 2019), "the greater the ACE, the stronger the El Niño", the association between the preceding strong (weak) ACE and EP (CP) El Niño demonstrated above might explain why CP El Niño is usually weaker than EP El Niño.

\subsection{Occurrence frequencies of EP and CP EI Niño months}

Occurrence frequencies of EP and CP El Niño months associated with the preceding WNP ACE are also computed. Results indicate that EP El Niño occurs more frequently than CP El Niño when the preceding ACE is strong, with the occurrence frequency of EP El Niño months about 1.67 times that of CP El Niño months (Fig. 7a), while the ratio of the total value of the preceding ACE between EP El Niño and CP El Niño is higher at 1.87 (Fig. 7b). This feature indicates that although CP El Niño months still occur when the preceding ACE is strong, the strength of the preceding ACE is lower than that associated with EP El Niño months. On the contrary, when the preceding ACE is weak, the occurrence frequency of CP El Niño is about 6.5 times that of
EP El Niño (Fig. 7a) and the ratio of the total value of the preceding ACE between CP El Niño and EP El Niño is also about 6.5 (Fig. 7b). This result indicates that although the strength of the preceding ACE related to CP El Niño months is equivalent to that related to EP El Niño months, CP El Niño months clearly occur more frequently than EP El Niño months when the preceding ACE is weak. Overall, when the preceding ACE is strong, EP El Niño months occur more frequently; when the preceding ACE is weak, CP El Niño months occur more frequently.

\subsection{Possible influence of the WNP TCs on the interannual shift of El Niño events}

Previous studies have pointed out that there was an evident shift in El Niño from EP to CP El Niño in 1999/2000 (Lee and McPhaden 2010; Wang et al. 2016; Hu et al. 2020). As shown in Fig. 8a, the strength of the WNP ACE anomalies also has an evident shift from positive to negative in 1997/1998. Given the weaker ACE observed after 1997/1998, the more frequent occurrence of CP El Niño when the preceding WNP ACE is weak may explain the greater number of CP El Niño events after 1999/2000. The lead-lag relationship between the WNP ACE and tropical SST anomalies also indicates that the change of the WNP ACE leads that of SST anomalies (Fig. 9a). There is an assumption that needs to be justified here: the interdecadal shift of the WNP ACE may result from the change of SST anomalies because the WNP ACE and simultaneous (zero lag) tropical SST anomalies are positively correlated (Fig. 9a). However, after removing this signal of simultaneous SST anomalies, the interdecadal shift of ACE at the year 1997/1998 still exists (Fig. 8b). Furthermore, when the yearly data are used, the result is still robust (Fig. 8c, d) although there is high simultaneous correlation between the yearly ACE and tropical SST anomalies (Fig. 9b).

\section{El Niño cases related to the preceding ACE strength}

To further examine the influence of TCs on the spatial pattern of El Niño, we study the El Niño events in terms of the preceding ACE strength (see Sect. 2.4). As shown in Fig. 10, an El Niño case associated with the preceding strong ACE (El Niño_strong ACE) is stronger than the mean El Niño, and an El Niño case associated with the preceding weak ACE (El Niño_weak ACE) is weaker. This result is consistent with the previous study (Wang et al. 

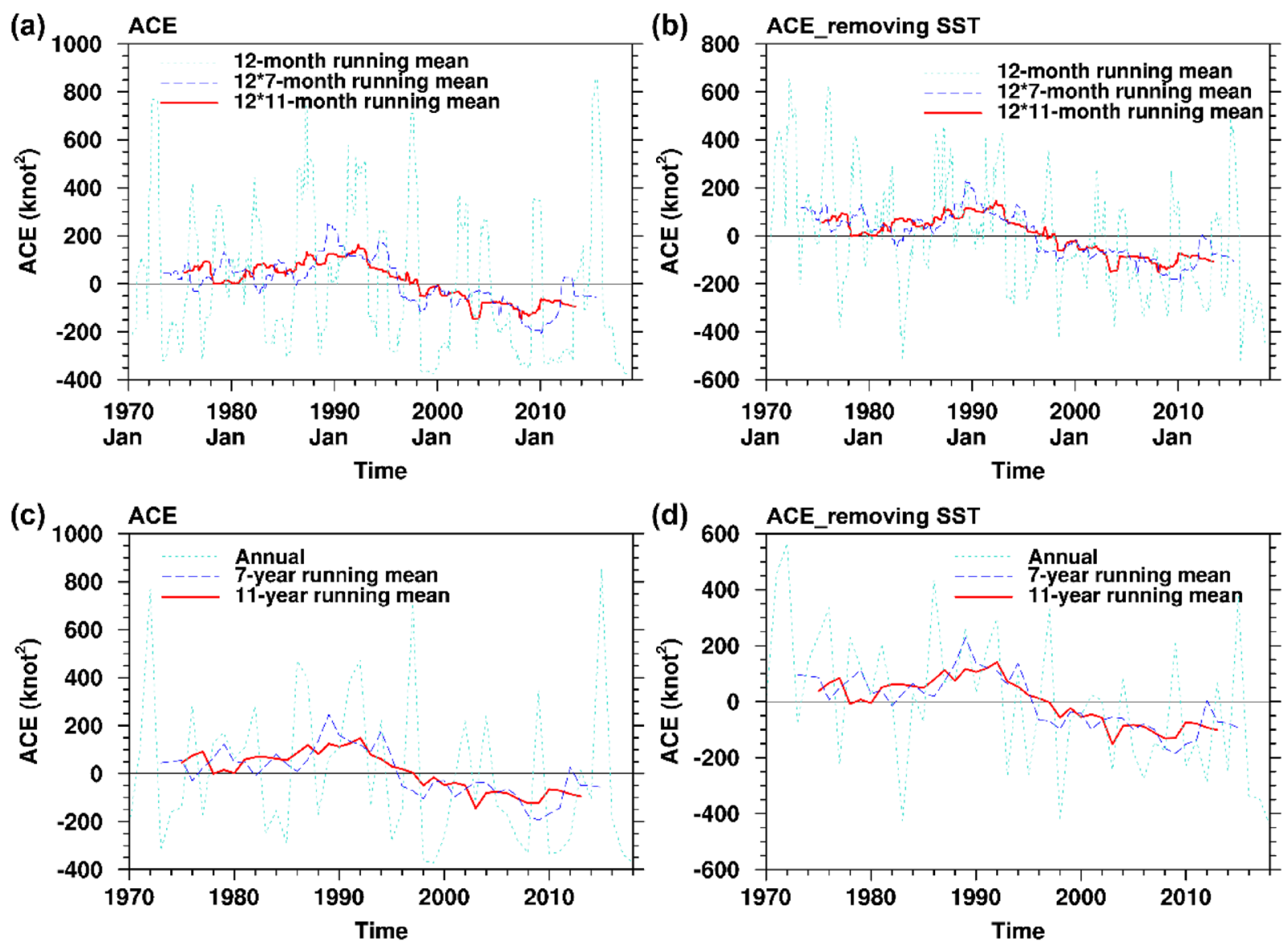

Fig. 8 Time series of the WNP ACE anomalies $\left(\operatorname{knot}^{2}\right)$ in the period 1970-2018. a Raw monthly series. Turquoise dotted line represents the 12-month running mean ACE, blue dashed line the $12 \times 7$-month running mean ACE, and the red solid line is the $12 \times 11$-month running mean ACE. $\mathbf{b}$ As in $\mathbf{a}$, but for the series after removing the sig-

nal of simultaneous SST $\left(5^{\circ} \mathrm{S}-5^{\circ} \mathrm{N}, 160^{\circ} \mathrm{E}-90^{\circ} \mathrm{W}\right)$. c Raw yearly series. Turquoise dotted line represents the annual ACE, blue dashed line the 7-year running mean ACE, and red solid line the 11-year running mean ACE. $\mathbf{d}$ As in $\mathbf{c}$, but after removing the simultaneous SST $\left(5^{\circ} \mathrm{S}-5^{\circ} \mathrm{N}, 160^{\circ} \mathrm{E}-90^{\circ} \mathrm{W}\right)$

2019). The position of the center of maximum SST anomalies during El Niño_strong ACE is similar to that during the mean El Niño, in the eastern Pacific (Fig. 10a, b). However, the center during El Niño_weak ACE moves to the centralwestern Pacific (Fig. 10c). The distributions of anomalous SST after removing the local SST anomalies, zonal wind anomalies over the tropical central-western Pacific or MJO are checked (Fig. 11). As shown in Fig. 11a, when the preceding SST anomalies in the Niño-3.4 region are removed, the intensity of El Niño is clearly reduced. Similarly, when the other preceding factors are removed, the intensities of El Niño are all weakened (Fig. 11b-d). Removing the preceding zonal wind anomalies over the tropical central-western Pacific weakens the SST amplitude the most, followed by removing the preceding SST anomalies in the Niño-3.4

region, the SST anomalies in the tropical western Pacific and the MJO (Fig. 11). Nevertheless, whatever the case, in the El Niño_strong ACE case, the center of the maximum positive SST anomalies is still located in the eastern Pacific and in the El Niño_weak ACE case, the center occurs in the central-western Pacific.

In addition, the distributions of MJO phases during the strong ACE and weak ACE events are checked in Fig. 12. The results indicate that the phase distribution is similar in the strong ACE and weak ACE events (Table 1). Furthermore, we count the number of days during the strong $\mathrm{ACE}$ and weak ACE events that correspond to active and inactive MJO events and non-MJO event. During strong ACE event, there are 860 days related to active MJO events, 791 days to inactive MJO events, and 1097 days 


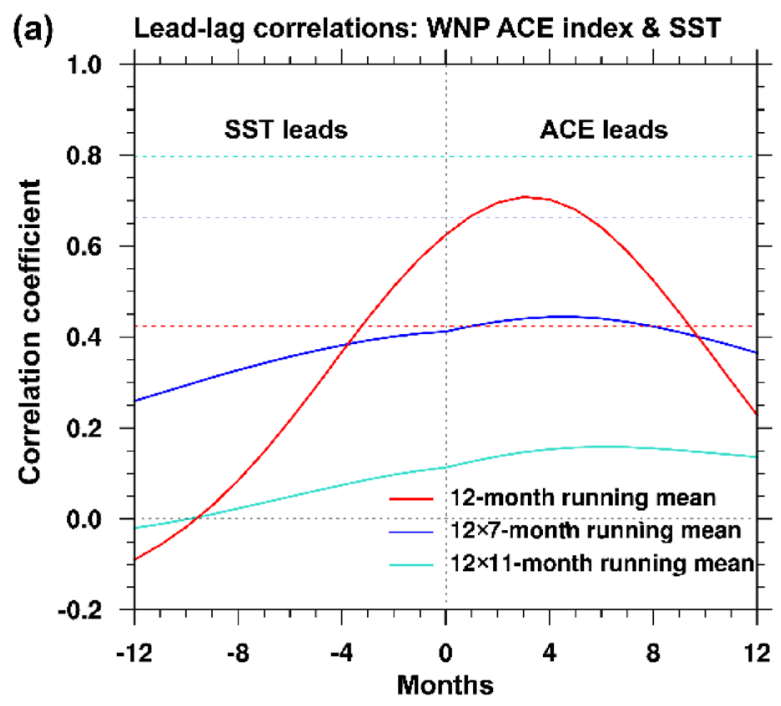

Fig. 9 Lead-lag correlation between the WNP ACE anomalies and tropical SST anomalies $\left(5^{\circ} \mathrm{S}-5^{\circ} \mathrm{N}, 160^{\circ} \mathrm{E}-90^{\circ} \mathrm{W}\right)$. a Monthly series. The red, blue and turquoise dashed lines indicate significance at the $99 \%$ confidence level related to the $12-, 12 \times 7-$ and

to non-MJO events. During weak ACE event, there are 902 days related to active MJO events, 889 days to inactive MJO events, and 1974 days to non-MJO events. In general, the non-MJO events occur most often. These features further suggest that the impact of TCs on El Niño diversity on an interannual timescale shows a little dependency on the MJO.

Overall, in the El Niño_strong ACE case, the center of the maximum positive SST anomalies occurs in the equatorial eastern Pacific, showing the spatial pattern of EP El Niño event; In the El Niño_weak ACE case, the center of the maximum positive SST anomalies occurs in the equatorial central-western Pacific, showing the spatial pattern of CP El Niño event. It's no doubt that the preceding SST anomalies in the Niño-3.4 region, SST anomalies in the tropical western Pacific and zonal wind anomalies over the tropical central-western Pacific all contribute to the development of El Niño, the intensity of El Niño is reduced after removing these three signals. Thereinto, the preceding zonal wind anomalies over the tropical central-western Pacific and SST anomalies in the Niño-3.4 region have the biggest contributions. Nevertheless, after removing these signals, the locations of the maximum SST anomalies centers in El Niño_strong ACE and El Niño_weak ACE cases still remain unchanged. In addition, the MJO has a little impact on the modulation of the WNP TCs on El Niño diversity on an interannual timescale.

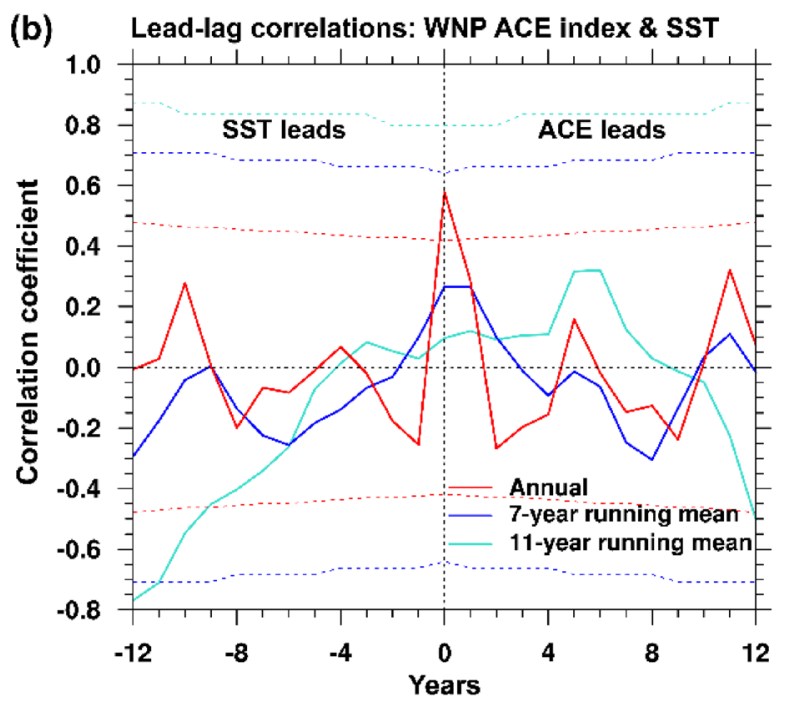

$12 \times 11$-month running mean series, respectively. b Annual series. The red, blue and turquoise dashed lines indicate significance at the $99 \%$ confidence level related to the annual, 7-, and 11-year running mean series, respectively

\section{Summary and discussion}

The first part of this two-part study explores the feedback of the WNP TCs on El Niño diversity from two aspects, including the traditional types of El Niño events (EP and CP El Niño) and El Niño cases related to the preceding ACE events (El Niño_strong ACE and El Niño_weak ACE). And results demonstrated that this feedback shows a little dependency on the local SST anomalies (including in the Niño-3.4/Niño-3/Niño-4 region and tropical western Pacific), zonal wind anomalies over the tropical centralwestern Pacific and the MJO. From the perspective of the traditional two types of El Niño events, the evidence shows the preceding WNP ACE can reproduce well the spatial characteristics of SST anomalies except for the underestimation of intensity. And from the perspective of the El Niño cases related to the preceding ACE events, results indicate the center of the maximum SST anomalies during El Niño_strong ACE is located in the equatorial eastern Pacific, showing the spatial pattern of EP El Niño; On the contrary, the center during El Niño_weak ACE moves to the central-western Pacific, showing the spatial pattern of CP El Niño. Overall, when the preceding ACE is strong, it favors the occurrence of EP El Niño events; when the preceding ACE is weak, it favors the occurrence of CP El Niño events. Note that the weaker ACE after 1997/1998 may explain the increased frequency of CP El Niño after 1999/2000. As EP 
Fig. 10 Spatial distribution of SST anomalies $\left({ }^{\circ} \mathrm{C}\right)$ during different El Niño cases in the period 1970-2018. a Composite of El Niño months. b Composite of El Niño_strong ACE; i.e., the El Niño months when strong ACE events occur 3 months earlier. c Composite of El Niño_ weak ACE; i.e., the El Niño months when weak ACE events occur 3 months earlier
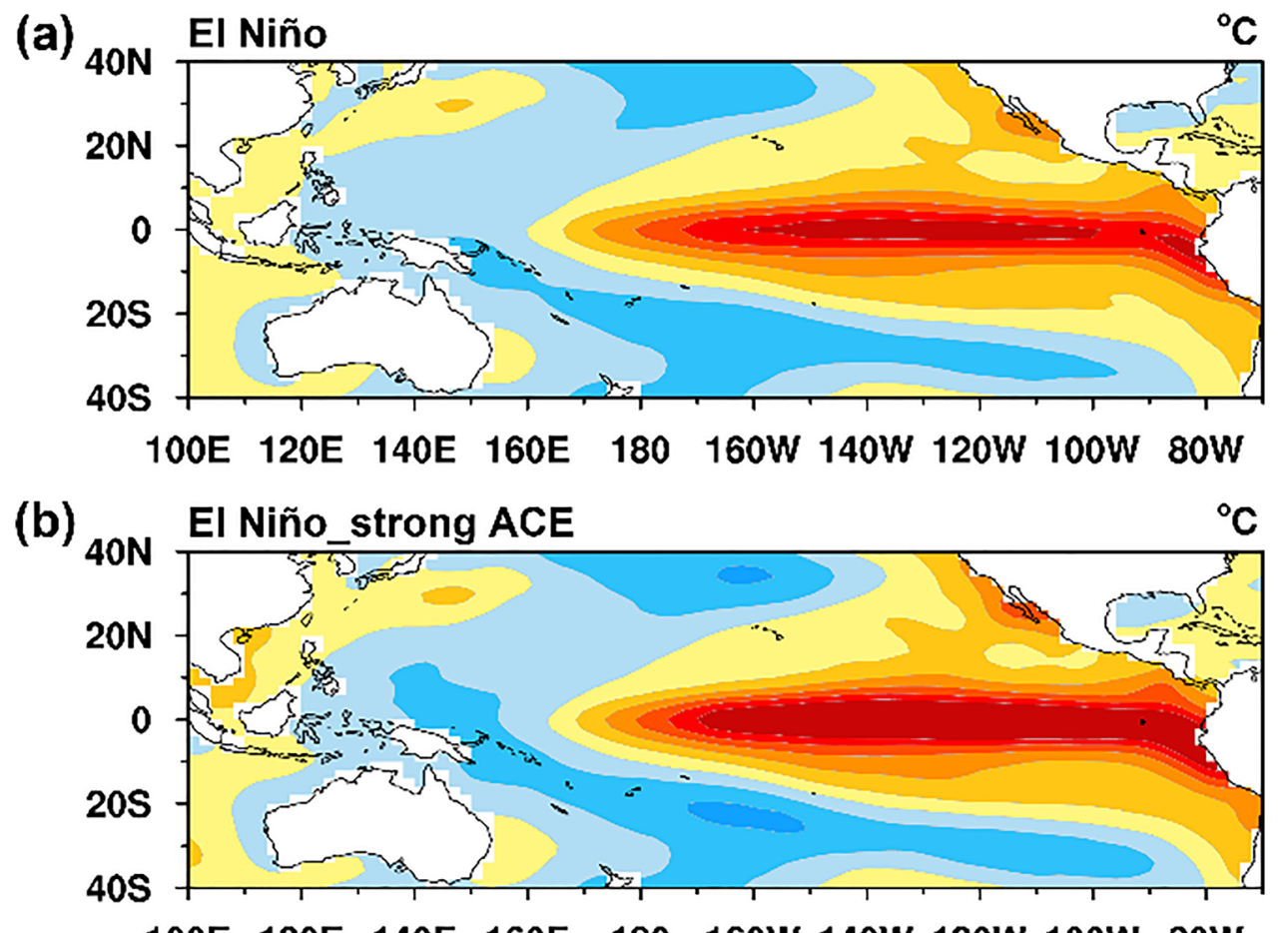

(c) 100E 120E 140E 160E 180 160W 140W 120W 100W 80W
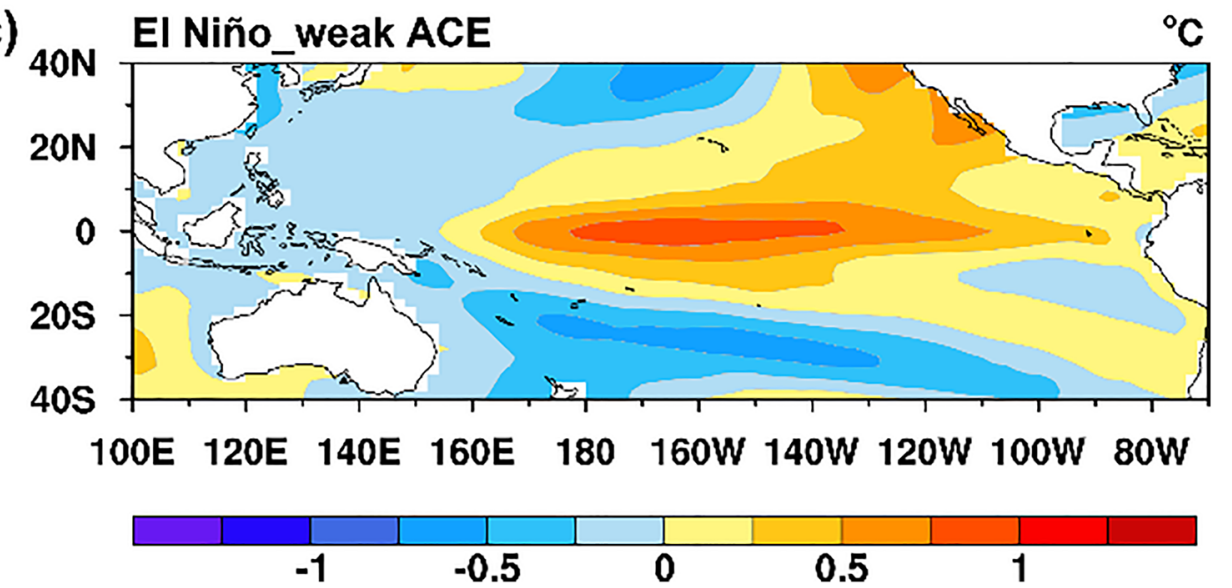

(CP) El Niño events are usually associated with preceding strong (weak) ACE events. This may be one reason why $\mathrm{CP}$ El Niño is usually weaker than EP El Niño.

Results in this paper imply that the WNP TCs may be an important factor affecting El Niño diversity, and also provide evidence that TCs can have a cumulative effect on El Niño. It's no doubt that there is a two-way interaction between WNP TCs and two types of El Niño. It is necessary to further verify the relationship between the WNP TCs and two types of El Niño in a fully coupled model in future work, especially the impact of the WNP TCs on two types of El Niño. This has been difficult to achieve because of the limitations of current models in modeling the interannual variabilities of both TC activity and El Niño. And the physical mechanism how the WNP TCs affect El Niño diversity also need further study, which will be discussed in Part II of this study. Meanwhile, the local SST anomalies, thermocline variations (Ashok et al. 2007), zonal advective feedback (Kug et al. 2009), WWBs (Chen et al. 2015; Fedorov et al. 2015) and subtropical forcing (Yu et al. 2010; Feng et al. 2014; Ding et al. 2017) also play important roles in El Niño diversity, WNP TC is just one of the impact factors 


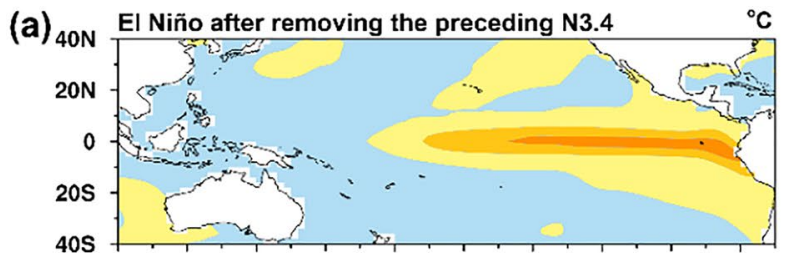

100E 120E 140E 160E 180 160W 140W 120W 100W 80W

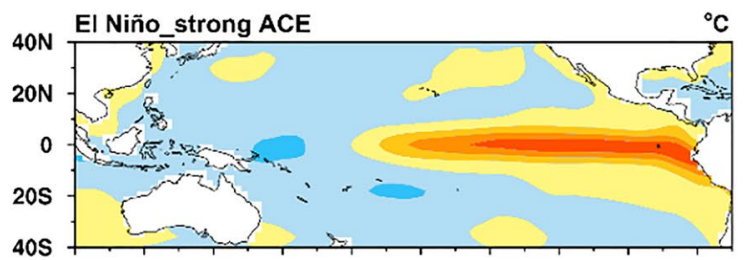

100E 120E 140E 160E 180 160W 140W 120W 100W 80W

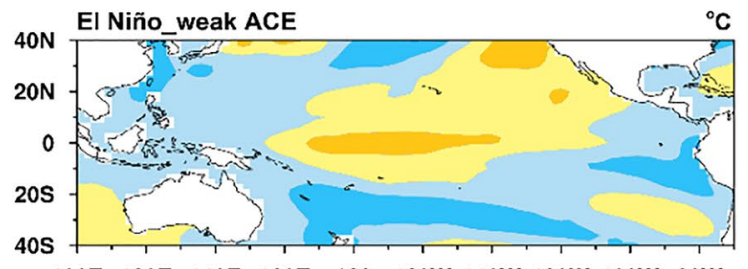

100E 120E 140E 160E 180 160W 140W 120W 100W 80W

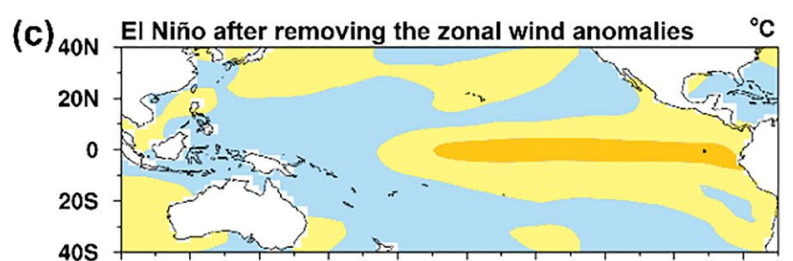

100E 120E 140E 160E 180 160W 140W 120W 100W 80W

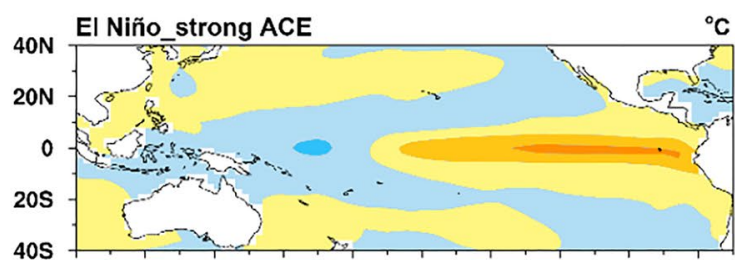

100E 120E 140E 160E 180 160W 140W 120W 100W 80W

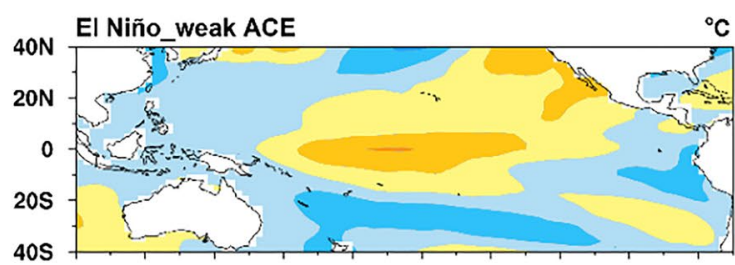

100E 120E 140E 160E 180 160W 140W 120W 100W 80W
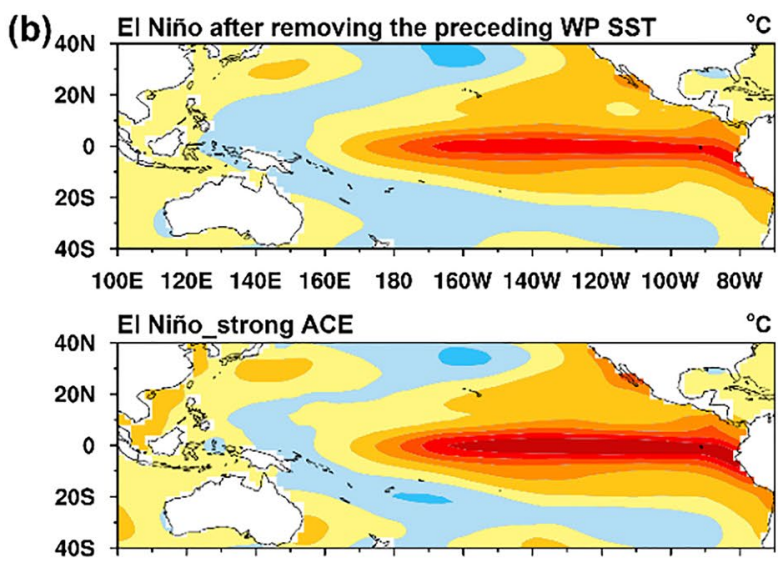

100E 120E 140E 160E 180 160W 140W 120W 100W 80W
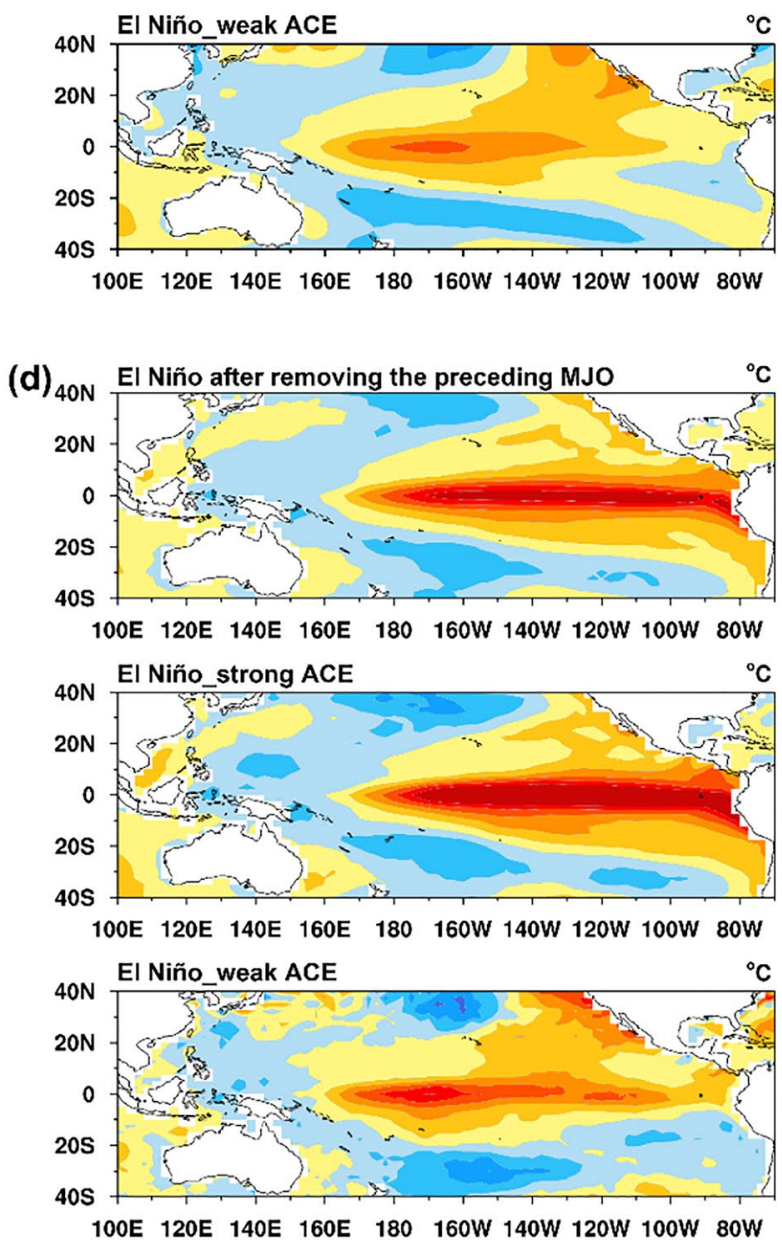

100E 120E 140E 160E 180 160W 140W 120W 100W 80W

\section{$-1.25$ \\ $-0.75$}

Fig. 11 As in Fig. 10, but for El Niño cases after removing the different preceding impact factors, and the corresponding El Niño_strong ACE and El Niño_weak ACE. a Removing the preceding Niño-3.4 index. b Removing the preceding the SST anomalies in the tropical

of El Niño diversity. The relative contributions of WNP TCs and other factors on El Niño diversity still need to be quantified. Moreover, in this study, we suggest that WNP western Pacific $\left(10^{\circ} \mathrm{S}-10^{\circ} \mathrm{N}, 120^{\circ}-160^{\circ} \mathrm{E}\right)$. c Removing the zonal wind anomalies in the tropical central-western Pacific $\left(10^{\circ} \mathrm{S}-10^{\circ}\right.$ $\left.\mathrm{N}, 120^{\circ} \mathrm{E}-120^{\circ} \mathrm{W}\right)$. d Removing the MJO signal, here, SST data is from the ERA Interim dataset

TCs may have an important role in the interdecadal shift of El Niño events; On this shift of El Niño, previous studies (Hu et al. 2012, 2020; Li et al. 2019; Wengel et al. 2021) 
Fig. 12 Phase distribution of the daily $\mathrm{MJO}$ indices in the period 1979-2018. One dot is one day. a During the strong ACE events. b During the weak ACE events
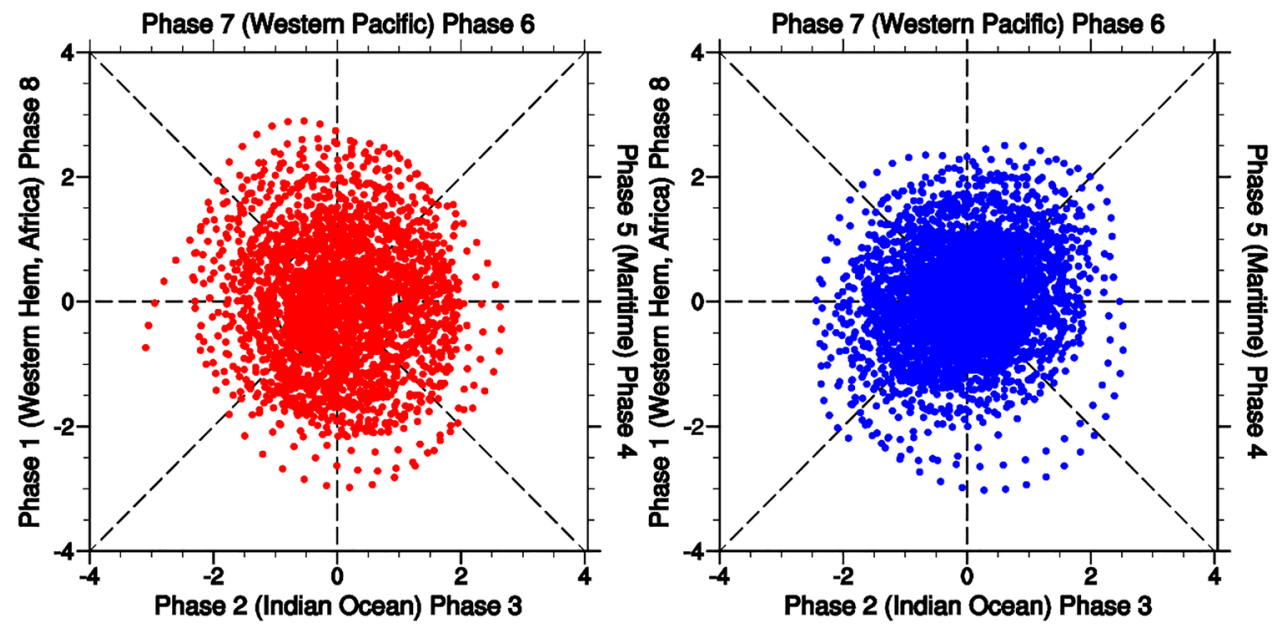

Table 1 Occurrence frequency of MJO phases and the corresponding $\mathrm{MJO}$ and Non-MJO events during the strong ACE and weak ACE events in the period 1979-2018

\begin{tabular}{lll}
\hline & During strong ACE events & $\begin{array}{l}\text { During weak } \\
\text { ACE events }\end{array}$ \\
\hline Phase 1 & 153 & 280 \\
Phase 2 & 237 & 249 \\
Phase 3 & 228 & 149 \\
Phase 4 & 213 & 169 \\
Phase 5 & 202 & 256 \\
Phase 6 & 216 & 286 \\
Phase 7 & 229 & 191 \\
Phase 8 & 173 & 211 \\
Active MJO (phases 4-7) & 860 & 902 \\
Inactive MJO (phases & 791 & 889 \\
1-3, phase 8) & & \\
Non-MJO & 1097 & 1974 \\
\hline
\end{tabular}

indicated that it might largely be associated with the mean state change in the tropical Pacific, which is also consistent with projections of ENSO in a warmer climate. Hence, the role of TC in this interdecadal shift needs more evidence and detailed investigation. In addition, it is well known that the different phase of ENSO has the distinct impact on the WNP TCs (Ha et al. 2012; Han et al. 2016), which means that the feedback of WNP TCs on the different phase of ENSO may be distinct. This question needs to be further explored.

Funding This work was jointly supported by the National Natural Science Foundation of China (NSFC, 42105014 and 41530424) projects, Shandong Natural Science Foundation Project (ZR2019ZD12), Postdoctoral Research Foundation of China (2021T140302, 2021M701652) and Fundamental Research Funds for the Central Universities (201962009).
Data availability Tropical cyclone data can be found at https://www. ncdc.noaa.gov/ibtracs/. The interpolated outgoing longwave radiation data is available at https://www.esrl.noaa.gov/psd/data/gridded/data. interp_OLR.html. Monthly sea surface temperature is available at https://www.esrl.noaa.gov/psd/data/gridded/data.noaa.ersst.v5.html. Daily sea surface temperature is obtained from https://apps.ecmwf. int/datasets/data/interim-full-daily/levtype $=\mathrm{sfc} /$. Monthly wind data is available at https://www.esrl.noaa.gov/psd/.

Code availability Computer code used for the analysis was written in NCL, all types of figures that occur in this study can be found in NCL application examples (available online at https://www.ncl.ucar. edu/Applications/). More specific codes in this study are available to readers upon request.

\section{Declarations}

Conflict of interest The authors declare no competing interests.

Open Access This article is licensed under a Creative Commons Attribution 4.0 International License, which permits use, sharing, adaptation, distribution and reproduction in any medium or format, as long as you give appropriate credit to the original author(s) and the source, provide a link to the Creative Commons licence, and indicate if changes were made. The images or other third party material in this article are included in the article's Creative Commons licence, unless indicated otherwise in a credit line to the material. If material is not included in the article's Creative Commons licence and your intended use is not permitted by statutory regulation or exceeds the permitted use, you will need to obtain permission directly from the copyright holder. To view a copy of this licence, visit http://creativecommons.org/licenses/by/4.0/.

\section{References}

Ashok K, Behera SK, Rao SA, Weng HY, Yamagata T (2007) El Niño Modoki and its possible teleconnection. J Geophys ResOceans 112:C11007

Battisti DS, Hirst AC (1989) Interannual variability in a tropical atmosphere ocean model-influence of the basic state, ocean geometry and nonlinearity. J Atmos Sci 46:1687-1712 
Bell GD, Halpert MS, Schnell RC, Higgins RW, Lawrimore J, Kousky VE, Tinker R, Thiaw W, Chelliah M, Artusa A (2000) Climate assessment for 1999. B Am Meteorol Soc 81:S1-S50

Bjerknes J (1969) Atmospheric teleconnections from the equatorial Pacific. Mon Weather Rev 97:163-172

Camargo SJ, Sobel AH (2005) Western North Pacific tropical cyclone intensity and ENSO. J Clim 18:2996-3006

Chan JCL (2007) Interannual variations of intense typhoon activity. Tellus A 59:455-460

Chen D, Cane MA, Kaplan A, Zebiak SE, Huang DJ (2004) Predictability of El Niño over the past 148 years. Nature 428:733-736

Chen DK, Lian T, Fu CB, Cane MA, Tang YM, Murtugudde R, Song XS, Wu QY, Zhou L (2015) Strong influence of westerly wind bursts on El Niño diversity. Nat Geosci 8:339-345

Chen GH, Tam CY (2010) Different impacts of two kinds of Pacific Ocean warming on tropical cyclone frequency over the western North Pacific. Geophys Res Lett 37:L01803

Chia HH, Ropelewski CF (2002) The interannual variability in the genesis location of tropical cyclones in the northwest Pacific. J Clim 15:2934-2944

Choi Y, Ha K-J, Jin F-F (2019) Seasonality and El Niño Diversity in the Relationship between ENSO and Western North Pacific Tropical Cyclone Activity. J Clim 32:8021-8045

Ding RQ, Li JP, Tseng YH, Sun C, Xie F (2017) Joint impact of North and South Pacific extratropical atmospheric variability on the onset of ENSO events. J Geophys Res-Atmos 122:279-298

Fedorov AV, Hu SN, Lengaigne M, Guilyardi E (2015) The impact of westerly wind bursts and ocean initial state on the development, and diversity of El Niño events. Clim Dynam 44:1381-1401

Feng JX, Wu ZH, Zou XL (2014) Sea surface temperature anomalies off Baja California: a possible precursor of ENSO. J Atmos Sci 71:1529-1537

Ha K-J, Yoon S-J, Yun K-S, Kug J-S, Jang Y-S, Chan JCL (2012) Dependency of typhoon intensity and genesis locations on El Niño phase and SST shift over the western North Pacific. Theor Appl Climatol 109:383-395

Han R, Wang H, Hu Z-Z, Kumar A, Li W, Long LN, Schemm J-KE, Peng P, Wang W, Si D, Jia X, Zhao M, Vecchi GA, LaRow TE, Lim Y-K, Schubert SD, Camargo SJ, Henderson N, Jonas JA, Walsh KJE (2016) An assessment of multimodel simulations for the variability of western North Pacific tropical cyclones and its association with ENSO. J Clim 29:6401-6423

Hart RE (2011) An inverse relationship between aggregate northern hemisphere tropical cyclone activity and subsequent winter climate. Geophys Res Lett 38:L01705

Hart RE, Maue RN, Watson MC (2007) Estimating local memory of tropical cyclones through MPI anomaly evolution. Mon Weather Rev 135:3990-4005

Hu Z-Z, Kumar A, Jha B, Huang B (2012) An analysis of forced and internal variability in a warmer climate in CCSM3. J Clim 25:2356-2373

Hu Z-Z, Kumar A, Huang BH, Zhu JH, L'Heureux M, McPhaden MJ, Yu JY (2020) The interdecadal shift of ENSO properties in 1999/2000: a review. J Clim 33:4441-4462

Huang BY, Thorne PW, Banzon VF, Boyer T, Chepurin G, Lawrimore JH, Menne MJ, Smith TM, Vose RS, Zhang HM (2017) Extended reconstructed sea surface temperature, Version 5 (ERSSTv5): upgrades, validations, and intercomparisons. J Clim 30:8179-8205

Jin F-F (1997) An equatorial ocean recharge paradigm for ENSO.1. Conceptual Model J Atmos Sci 54:811-829

Jin F-F, Boucharel J II, Lin, (2014) Eastern Pacific tropical cyclones intensified by El Niño delivery of subsurface ocean heat. Nature 516:82-U178
Kalnay E, Kanamitsu M, Kistler R, Collins W, Deaven D, Gandin L, Iredell M, Saha S, White G, Woollen J, Zhu Y, Chelliah M, Ebisuzaki W, Higgins W, Janowiak J, Mo KC, Ropelewski C, Wang J, Leetmaa A, Reynolds R, Jenne R, Joseph D (1996) The NCEP/NCAR 40-year reanalysis project. B Am Meteorol Soc 77:437-471

Kang NY, Kim D, Elsner JB (2019) The contribution of super typhoons to tropical cyclone activity in response to ENSO. Sci Rep-Uk 9:5046

Keen RA (1982) The role of cross-equatorial tropical cyclone pairs in the Southern Oscillation. Mon Weather Rev 110:1405-1416

Kim HM, Webster PJ, Curry JA (2011) Modulation of North Pacific tropical cyclone activity by three phases of ENSO. J Clim 24:1839-1849

Kug JS, Ham YG (2011) Are there two types of La Niña? Geophys Res Lett 38:L16704

Kug JS, Jin F-F, An SI (2009) Two types of El Niño events: Cold tongue El Niño and warm pool El Niño. J Clim 22:1499-1515

Lee T, McPhaden MJ (2010) Increasing intensity of El Niño in the central-equatorial Pacific. Geophys Res Lett 37:L14603

Li XF, Hu Z-Z, Becker E (2019) On the westward shift of tropical Pacific climate variability since 2000. Clim Dyn 53:2905-2918

Lian T, Chen D, Tang Y, Liu X, Feng J, Zhou L (2018) Linkage between westerly wind bursts and tropical cyclones. Geophys Res Lett 45:11431-11438

McPhaden MJ (1999) Genesis and evolution of the 1997-98 El Niño. Science 283:950-954

Patricola CM, Camargo SJ, Klotzbach PJ, Saravanan R, Chang P (2018) The influence of ENSO flavors on western North Pacific tropical cyclone activity. J Clim 31:5395-5416

Puy M, Vialard J, Lengaigne M, Guilyardi E (2016) Modulation of equatorial Pacific westerly/easterly wind events by the MaddenJulian oscillation and convectively-coupled Rossby waves. Clim Dyn 46:2155-2178

Ren HL, Zheng F, Luo JJ, Wang R, Liu MH, Zhang WJ, Zhou TJ, Zhou GQ (2020) A review of research on tropical air-sea interaction, ENSO dynamics, and ENSO prediction in China. J Meteorol ResPrc 34:43-62

Schenkel BA, Hart RE (2015) An examination of the thermodynamic impacts of western North Pacific tropical cyclones on their tropical tropospheric environment. J Clim 28:7529-7560

Schopf PS, Suarez MJ (1988) Vacillations in a coupled ocean atmosphere model. J Atmos Sci 45:549-566

Shin J, Park S (2020) Impacts of ENSO and Madden-Julian oscillation on the genesis of tropical cyclones simulated by general circulation models and compared to observations. Environ Res Lett 15:4046

Sobel AH, Camargo SJ (2005) Influence of western North Pacific tropical cyclones on their large-scale environment. J Atmos Sci 62:3396-3407

Sriver RL, Huber M, Chafik L (2013) Excitation of equatorial Kelvin and Yanai waves by tropical cyclones in an ocean general circulation model. Earth Syst Dynam 4:1-10

Wada A, Chan JCL (2008) Relationship between typhoon activity and upper ocean heat content. Geophys Res Lett 35:L17603

Wang B, Barcilon A, Fang Z (1999) Stochastic dynamics of El NiñoSouthern Oscillation. J Atmos Sci 56:5-23

Wang B, Chan JCL (2002) How strong ENSO events affect tropical storm activity over the Western North Pacific. J Clim 15:1643-1658

Wang CZ, Deser C, Yu JY, DiNezio P, Clement A (2016) El NiñoSouthern Oscillation (ENSO): a review. Coral Reefs of the Eastern Pacific. In: Glynn PW, Manzello DP, Enochs IC (eds). Springer Science Publisher, pp 85-106. 
Wang CZ, Li CX, Mu M, Duan WS (2013) Seasonal modulations of different impacts of two types of ENSO events on tropical cyclone activity in the western North Pacific. Clim Dyn 40:2887-2902

Wang QY, Li JP, Jin F-F, Chan JCL, Wang CZ, Ding RQ, Sun C, Zheng F, Feng J, Xie F, Li YJ, Li F, Xu YD (2019) Tropical cyclones act to intensify El Niño. Nat Commun 10:3793

Weisberg RH, Wang CZ (1997) A western Pacific oscillator paradigm for the El Niño Southern Oscillation. Geophys Res Lett 24:779-782

Wengel C, Lee SS, Stuecker MF, Timmermann A, Chu JE, Schloesser F (2021) Future high-resolution El Niño/Southern Oscillation dynamics. Nat Clim Change 11:758

Wheeler MC, Hendon HH (2004) An all-season real-time multivariate MJO index: development of an index for monitoring and prediction. Mon Weather Rev 132:1917-1932

Wyrtki K (1985) Water displacements in the Pacific and the genesis of El Niño cycles. J Geophys Res-Oceans 90:7129-7132

Xie F, Zhou X, Li JP, Chen QL, Zhang JK, Li Y, Ding RQ, Xue JQ, Ma X (2018) Effect of the Indo-Pacific warm pool on lower-stratospheric water vapor and comparison with the effect of ENSO. J Clim 31:929-943

Yu JY, Kao HY, Lee T (2010) Subtropics-related interannual sea surface temperature variability in the central equatorial Pacific. J Clim 23:2869-2884

Zebiak SE, Cane MA (1987) A model El-Niño Southern Oscillation. Mon Weather Rev 115:2262-2278

Zhan RF, Wang YQ, Lei XT (2011) Contributions of ENSO and East Indian Ocean SSTA to the interannual variability of Northwest Pacific tropical cyclone frequency. J Clim 24:509-521

Zhao HK, Yoshida R, Raga GB (2015) Impact of the MaddenJulian Oscillation on western North Pacific tropical cyclogenesis associated with large-scale patterns. J Appl Meteorol Clim 54:1413-1429

Publisher's Note Springer Nature remains neutral with regard to jurisdictional claims in published maps and institutional affiliations. 